DOI 10.31392/NPU-nc.series 15.2020.5(125).01

Kaplinskyi V. V. Doctor of Science in Pedagogy, Associate Professor of Pedagogy and Professional Education Department, Mykhailo Kotsiubynskyi Vinnytsia State Pedagogical University Svyshch N. M. Lecturer of General and Practical Psychology Department Izmail State University of Humanities Grytsyk N. V. PhD in Pedagogy, Associate Professor, Associate Professor of Foreign Languages Department Taras Shevchenko National University "Chernihiv Collegium"

\title{
INFLUENCE ON EMOTIONAL SPHERE OF FUTURE TEACHER'S PERSONALITY IN THE PROCESS OF IT'S GENERAL PEDAGOGICAL TEACHER TRAINING ( PRACTICAL ASPECT)
}

The process of studying pedagogical disciplines in this direction almost wasn't researched. But the disciplines of the pedagogical cycle next to literature, history, culture hide in themselves an extraordinary educational potential, which under certain conditions could be aimed at successfully forming the future teacher's personality. This determines the relevance of the topic we have chosen. The educational process provides a consequence when its semantic component is evaluated not only through "the eyes of the curriculum", but also through "the eyes of students", their interests, the problems concerning them, needs, and value orientations. With this approach, it ceases to be a purely cognitive process, becoming personally significant. However, a successful consequence must be preceded, the purpose is set - the teacher's content focus of and actions are not only on the instrumental sphere of personality, but also necessarily on motivational value. Such a purpose becomes the compass that directs its action to the result (those positive changes in the structure of the personality that are a productive consequence).

Keywords: pedagogical disciplines, educational potential, personality formation, future teacher, value orientations, productive aftereffect.

Каплінський В. В., Свищ Н. М., Грицик Н. В. Вплив на емоційну сфреру особистості майбутнього вчетеля в процесі загальнопедагогічної підготовки (практичний аспект). Процес вивчення педагогічних дисциплін в цьому напрямку майже не досліджувався. Натомість дисципліни педагогічного ииклу поряд з літературою, історією, культурою, приховують в собі неабиякий виховний потенціал, який за певних умов міг би бути спрямованим на успішне формування особистості майбутнього вчителя. Це і зумовлює актуальність обраної нами теми. Навчально-виховний процес забезпечує післядію тоді, коли його змістовий компонент оцінюється не лише «очима навчальної програми», а i «очима студентів», їх інтересів, проблем, що їх хвилюють, потреб, ціннісних орієнтацій. При такому підході він перестає бути чисто пізнавальним процесом, стаючи особистісно значущим. Однак успішній післядії має передувати чітко поставлена иіль - націленість змісту і дій викладача не тільки на інструментальну сфферу особистості, а $i$ обов'язково на мотиваційно-ціннісну. Така ціль і стає тим компасом, який спрямовує його дії на результат (ті позитивні зміни в структурі особистості, які і являють собою продуктивну післядію).

Ключові слова: педагогічні дисципліни, виховний потенціал, формування особистості, майбутній учитель, ціннісні орієнтації, продуктивна післядія.

Каплинский $\quad$ В. В., Свищ Н. М., Грицик Н. В. Воздействие на эмоциональную сфреру личности будущего учителя в процессе общепедагогической подготовки (практический аспект). Процесс изучения педагогических дисциплин в этом направлении почти не исследовался. Зато дисциплины педагогического цикла наряду с литературой, историей, культурой, скрывают в себе большой воспитательный потенциал, который при определенных условиях мог бы быть направленным на успешное формирование личности будущего учителя. Это и обуславливает актуальность выбранной нами темы. Учебно-воспитательный прочесс обеспечивает последействие тогда, когда его содержательный компонент оценивается не только «глазами учебной программы», а и «глазами студентов», их интересов, проблем, которые волнуют, потребностей, ценностных ориентаций. При таком подходе он перестает быть чисто познавательным процессом, становясь личностно значимым. Однако успешной последействия должно предшествовать четко поставленная цель - нацеленность содержания и действий преподавателя не только на инструментальную сферу личности, а и обязательно на мотивационно-ценностную. Такая цель и становится тем компасом, который направляет его действия на результат (те положительные изменения в структуре личности, и представляют собой производительную последействие).

Ключевые слова: педагогические дисциплины, воспитательный потенциал, формирование личности, будущий учитель, ценностные ориентации, продуктивное последействие.

The statement of the problem. K.D.Ushinsky [1], V.O.Sukhomlynsky [2-3], V.M. Galuziak [4], other well-known educators have paid a lot of attention to the aftereffect of educational process. They assumed the successful result of the pedagogical process happen, when profound changes in the structure of the individual are observed, which arise and are based on external influences.

However, the role of pedagogical disciplines in this aspect has been hardly investigated. 
In return, the disciplines of the pedagogical cycle, including literature, history and culture, conceal in themselves a remarkable educational potential, which under certain conditions could be aimed at the successful formation of the personality of the future teacher [5-48]. This determines the relevance of the topic we have chosen.

The aim of the article is focusing attention of teachers of pedagogical disciplines on the conditions, under which the content enters the internal plan of the student's personality, "germinates" in his consciousness and provides a productive aftereffect.

The presentation of the main material. After graduation from higher educational pedagogical institution, some graduates do science, a part of them start their teaching career. Nevertheless, all graduates start an adult life.

However, in the study of pedagogy, we are more aimed at the first group, focussing on the scientific and terminological aspects of this science. Students study theoretical aspcts, definitions, show what they have learned to the teacher at the exam, and as a rule, they leave little to themselves.

The principle of connection of pedagogy with life, theory with practice is almost the most important principle of teaching pedagogy. After all, what is studied at lectures, seminars, in the process of independent work matters only when it becomes a guidance to action, in everyday life, a regulator of practical activity.

When a student at a seminar session gives a definition of education, he can name its trends, forms, etc., and we find this important. Nevertheless, if this knowledge does not become an instrument of life in action, it cannot be called acquired, because the process of learning which is stopped at the stage of consolidation, is not completed. It is known that the learning process is aimed at the development of the instrumental area of personality. Nevertheless, with such incomplete learning or not mastering of knowledge they do not become an instrument of action, thus they are dead. Moreover, the reason of this is that in the process of its learning the motivational-value area of the personality was not involved.

Pedagogy is an educational discipline that requires, first and foremost, the involvement of this particular area. Therefore, teaching pedagogy should be both training and education in the narrow sense, aimed at the formation of feelings, values orientations and beliefs.

If in the study of sciences, mathematics or physics, the path to consciousness can be direct and short (knowledge $\rightarrow$ consciousness), then when studying humanitarian pedagogy, it should be somewhat longer and pass through the area of emotions and feelings. First, the latter gives a signal about the vital importance or practical necessity of this knowledge. Only then, there is their adoption and the transition to the inner plane of personality. Before becoming an instrument and fixing in the instrumental field, knowledge must become a value, passing through the motivational and value area of personality.

The content of pedagogy as a science about e d u c a t i o $\mathrm{n}$ will never become a value for the student's personality, if he studies only by laws of pure education without referring to the area, which, properly speaking, fills the meaning, giving it a vital and subjective significance. The essence of education will be truly realized only when student $f$ e e I s the necessity, strength and significance of upbringing in the process of his study.

In connection with this, there is a necessity to update the content of pedagogical disciplines, its greater vicinity to life. Therefore, without going beyond the state standard, we try to fill the content of the disciplines of the pedagogical cycle with life by referring to the video footage of feature films on pedagogical subjects, the experience of the famous teachers of the past and our contemporaries, colleagues on work, fiction, poetry, etc.

It is precisely this approach that allows influencing the motivational-value area of personality and causes an aftereffect, which, in our opinion, is the main indicator of a productive study of pedagogy.

On the final lesson of pedagogy, which absorbs vital and professional aspects of the previous lessons, containing the most important cognitive and educational potential, the method of open sentences are used to check the influence of pedagogy on the motivational-value area of personality, its role and meaning in life and future professional activity. The phrase "for me personally, pedagogy was the subject which ..." students, not writing their surnames (mandatory condition), continue to write so:

- $\quad$... I know for sure that this subject has left a noticeable imprint in my

mind. That is right, in the mind. It is like a grain sown to one into well-picked earth, another - less picked one. Nevertheless, this grain will sprout. Personally, in my mind now there is a kind of war between the bad that I have, and the good that are formed under the influence of this subject...

- $\quad$... I liked this subject from the first lesson. Before that, I was like in a

fog. . Nevertheless, with the advent of pedagogy my life has changed. I began to look at people differently, changed my attitude to them. I have a younger brother, and I see that my parents bring him up incorrectly. He resists them. However, he obeys me. He became my "experimental rabbit", on which I practice pedagogy. Then he told all his to parents and also noticed changes. I want to thank you for showing the right path...

- $\quad$... Before studying this subject, I often had had troubles with my parents, with friends. On the second course I was almost expelled from the university. Now l've understood myself, became more methodological, organized, I have a goal in my life. Pedagogy was not just a subject for me, but a period of life in which I became different - better. This is what my parents often say to me now.

- $\quad$ Personally for me, pedagogy was the subject which awaken the quick in me which was considered to have died already and all that which have lost somewhere deep in me. After each class I was tight-fisted for things I could have done, but I didn't...

- $\quad$... You turned the light in my dark path on (this is hardly a coincidence). This subject is for life...

- $\quad$...l don't know about the rest, but as for me, your subject and you absorbed me...

- $\quad$...My friends say that l've changed. And that is due to pedagogy...

- $\quad$...Thanks to this subject I became more responsible, calm. It filled the gap inside me...

about it...

... This subject made me the person... I never was. I used to smoke, however, now I don't want to see it and think 
- $\quad$... It's the only subject I was genuinely interested in. Though it's difficult for me to fight laziness, but I have got a sense of direction and desire. It's not much, but it is a victory - my, your and pedagogy. Pedagogy has forced my desire for selfimprovement...

- $\quad$... I won't let pedagogy and you go out of my life, because, when I forget everything, I will fade out. And you have said 'The person has to glow'. I want to be this kind of person...

- $\quad$...I felt very acutely my drawbacks, downsides. If I were given a new life, I would live it in a different way. But the life gave me you and this subject. And now l'm not going to do foolishness...

- $\quad . . . I$ had a conversation with himself, recalled my deeds, actions, words. In most cases they were negative. Unfortunately, there is no possibility to fix it. But you can change yourself! Must change yourself! After each class of pedagogy which weren't only classes, but were life classes, I felt my consciousness rebooting...

- $\quad$ Coming home after each class we sit and share impressions. And we don't even realize that we talk only about pedagogy...

- $\quad$... I don't sit tight. I constantly try to improve. But it's difficult to achieve anything. Sometimes I want to give up. But coming to class of pedagogy you become unsatisfied with your weakness, because you get a boost for further fight with yourself...

- $\quad$... Though the lecture on self-education was the last, but I was in the process of doing it from our first class. Even the relations with my girlfriend have changed. I have given several times your examples, quoted you. Probably, you didn't notice it, but in those classes, when we watched episodes of movies, quite often I almost cried, though I tried to restrain myself on the outside.

- $\quad$.... As for me, pedagogy is the way of self-education for the better...

Seeing that the process of learning pedagogical disciplines involves students' preparation for organizing educational work at school, assessing any educational activity, it is necessary to proceed from the point that upbringing involves not only an external aspect (what's going on/happens, demonstrates, promotes, organizes in order for educational influence), also an internal aspect (those inner changes in the structure of personality which happen as a result of external impacts).

The external aspect is an important and essential component of upbringing. However, it doesn't always get inside and 'pass a filter'. So 'the real object of our pedagogical care in upbringing process, emphasized A.S. Makarenko, should be an attitude' $[49,327]$. The attitude is exactly 'the green light', which facilitates the transfer of upbringing information to the internal plan of pupil's personality. And after the internal acceptance of information based on ensuring a positive attitude to it, it may say about the result of upbringing - a consequence or those internal changes in the structure of personality without which the efficiency of external influences are quite low or null.

According to E. Thorndike, a famous American psychologist, a word 'upbringing' has different meanings. However, upbringing is upbringing only when it points at changes. We don't bring someone up, if we don't cause changes in him.

Let's choose from hundreds of anonymous seniors' and students' feedback those, which convincingly prove the impact of such upbringing. Some pieces of feedback directly reflect a consequence of one of the educational activities which was conducted by the winner of pedagogy competition Alexander Vykhovanents:

- $\quad$...I'm filled with positive emotions. Everything I have heard will remain in my heart and soul. I feel positive changes. I recognized myself in video episodes and discovered my drawbacks which I'm trying to overcome. I'm pleased that my dear people notice it...

- $\quad$... I have learned to control my feelings, deeds, actions. I seriously thought about my drawbacks. After the lecture on self-education when the student, invited by you, had conducted the episode of the educational lesson, I gave up smoking...

- $\quad$...No, I will never forget today's educational hour. I deliberately hesitated a little after it to go home alone. No, not alone, but together with those thoughts which appeared in me. On the way I was convincing myself that everyone has drawbacks, mistakes. However, I decided firmly on that day not to make common mistakes. And avoid new ones. The end... the silence... and we are so excited and we even haven't felt it...

- $\quad$... When I was sitting in the auditorium, my breath was taken away. Leaving the auditorium, I felt great changes in me which couldn't be put into words...

- $\quad$...What I have heard and observed was the good push to act. Especially the strong influence of episodes which seems to wake up and encourage acting...

- $\quad$... I have understood that I am on the wrong way, wasting my life and spending it on trifles.

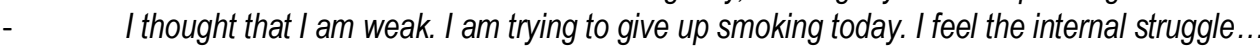

We offer a fragment of the educative event below, which Oleksandr Vyhovanets used on the All-Ukrainian competition in pedagogy. His purpose was to induce fighting with drawbacks which are obstacles on the way to the self-completion. Modelling of content of this event includes a combination of search and selection of videos which are related to the topic and at the same time meet needs of pupils' interests.

Topic: «Ways which we choose»

Presenter: There are 2 types of activity - external and internal. One famous person said: «Thoughts and minds have the big strength. Strength to win and to conquer our body». Our today's hour of communication doesn't demand the verbal activity from you as we'll talk about self-education. Its aim is to cause the internal dialogue, to think about intelligence of your own choice (self completion or self-destruction).

In my hands I have reflective essays of students of Physical Department after finishing the course of pedagogy. Their essays forced me to choose the topic of our conversation.

- $\quad$ Before studying pedagogy I was similar to a ship which lost its own reference point. One day I understood how is important to learn how to lead this ship by myself, having the right direction. Then I really changed my direction due to one person. I thank him for it... 
- $\quad$ The more efforts I make to achieve something in my life, the better I understand that I am in the serious moral stagnation and how rusted I am. I get stuck like that mechanical bird....

- $\quad$.... The bad things merge with us over time. We think that we'll be free from them when time comes. But time is flowing and bad things percolate into us deeper and deeper, causing serious problems and obstacles in the life. Sometimes they lead to a deadlock where you don't find an exit. Then you start to think why you didn't stop in time.....

- $\quad$..... I have many friends, who aren't on friendly terms with the law. The further away I start to notice that I can't control myself. Other things manage me and confuse the right way....

Here the words from a song by E.Krylatov will be appropriate: «Where are we going to make the next step. It is terrible if we have made the wrong step...»

Where will our next step be?

The first variant. Running on-site or constant skidding when you put aside everything for later. And then when time comes - you look back and it becomes bitter because of the pitiful state in which you see yourself. There, behind, there is emptiness without meaning. Years have passed, and the life hasn't begun yet ...

Then, the fragment from the film «Giant» comes: a boy, sitting on the bench, is in the state of stagnation. He leads the passive, lazy, aimless and empty life. His friend is passing near him and they have a short conversation:

- What were you doing all these days?

- Nothing.

- $\quad$ Nothing - is boring, guy, think about it.

- $\quad$ I have thought about it and from that time I began to think so much.

Then, the fragment from the film "Paying to another" comes, whose hero (the teenager) gives an interview to the teleporter after that he has understood the meaning of life and changed the way of thinking:

Now I think life is not such a shit. But it is not easy to accept those who are accustomed to that. They don't want to change anything. They raise their paws. And then they lose ...

Then on the screen the teacher of English speaks with her pupil (film «Dangerous thoughts»):

Sometimes we make mistakes and with these mistakes we continue to live further. You make the wrong choice everything goes awry...

Presenter: So where will our next step be?

The second variant. It's more dangerous and as a rule, it is a result of the first variant. You try to overcome an internal crisis, try to find an exit. But often, the support, which you have found, is wrong and leads you down more. Instead of going up you go down, you degrade; you don't realize that you use a program for self-destruction by yourself.

These words are supported by the fragment from the film "Let's live to Monday". On the screen there is a young, pretty teacher of English Natalia Sergeevna (Iryna Pechernikova). The button "stop" keeps the attention on her charming face.

Presenter: ... when this wonderful actress had an internal crisis, her friend decided to support her by offering a glass of brandy. Then in the theater she would "keep her face", but on the way home she bought brandy that to console and to hearten herself at home. One day she would try not to drink for a few days and would be terrified, realizing that she couldn't control herself. Then there was the time when only a penny for bread and food for a dog were left in her purse. Then she changed her Moscow apartment on a small hut in a village, where she still lives, encoded from alcohol. She is currently writing a book. She writes only a few lines every day just to delay the painful question: «What's next?» was not right ..."

Next, the button "Start" is pressed again. The actress's face comes alive, and it sounds from her mouth: "I'm sorry guys, I

Presenter: Sometimes you get into your hands another means of self-destruction. The one who takes a beautiful gesture with you from a beautiful pack. The internal voice alarmingly warns:

$\begin{array}{ll}\text { - } & \text { Stop! } \\ \text { - } & \text { Pull yourself together! } \\ \text { - } & \text { Listen to me! }\end{array}$

- $\quad$ Think about consequences!

- $\quad$ Be stronger than your desires!

- You have a dangerous weapon in your hands that strikes out twice: at you and at your children!

But you are will-less, you leave him without an answer, consciously making the next step down one more time.

After the teacher's words everyone pays their attention to the screen. The fragment of the lecture by a Russian academician is striking in its sharpness and frankness.

... When I see a girl who is smoking, I'm getting cold inside... Have you ever seen the birth? A child in the womb of the mother is in a special leather bag. There is amniotic fluid in this bag. In these waters, a child is swimming, developing. On the eve of childbirth the child breaks through this bag and amniotic fluid is moving off the birthing mother. After some time - the child is born immediately. But sometimes the child can't break this bag and is born right in the bag. We say about them: "They are born with a silver spoon in their mouths." Then this bag will be opened. If the woman's pregnancy was normal, we would see light waters, with a pleasant smell, and the pink baby floats in them. But if, God forbid, a woman in the course of pregnancy was smoking, or her husband was smoking, then after opening this bag - from there, just like from an ashtray with cigarette butts, - the heaviest tobacco spirit. The waters are muddy, dirty, and the blue child, half dead, with oxygen starvation, lies in this turbidity. If a smoking woman saw this, she would never take this poison in her mouth again ...

Then the face of the academician is replaced by the face of the young nice couple (the film "School bonds"). The boy and the girl are sitting at the table at the café, they are modern and attractive. The boy lights the girl's cigarette. A dialogue goes:

Don't you smoke? 
I tried but I didn't like it...

You are too good. Is it to impress mothers?

Which mothers?

All your girlfriends' mothers.

No, I do not have much practice.

You differ from other boys so much.

How?

You have a serious approach to life.

Host: When I was personally offered a cigarette, I imagined the scales and weighed: for one scale I put the so-called short-term pleasure, and on the second - those problems that it generates and slavish dependence. Refusing, I felt joy from a small victory over myself.

So where is our next step?

The third variant.

Enlightenment: I live wrongly. And if I continue this way, I will not have a future. My mechanical bird got confused and stuck from the powerlessness between the branches, stopped the flight. And a voice within me says again:

- Don't give up!

- $\quad$ Gain victory over yourself!

- $\quad$ Don't be afraid of defeat!

- Clear your height!

- $\quad$ Your future depends on your determination!

I overpower myself and decide - to stop, to change the way of life and way of thinking. I break away from the negative environment and begin my way of improving myself. My thoughts go into my actions...

There is the fragment of the film "Giant" on the screen again:

The guy is coming up to a tree in which the bird is stuck in the branches. He takes it off, starts it and launches it again into the sky, admiring its free flight in the blue sky (the metaphor for the exit from the state of stagnation and insertion in the active performance). The flight of a bird is stopped by a fragment of the film D. Asanova "Boys". The scene of enlightenment of the hero of the film, Rublev, who was betrayed by his "so-called" friend Zaitsev, who constantly manipulated him, finally appreciates the true and sincere care of his coach Pasha, whom he still resisted. There is an explosion in Rublev's mind. Running after Zaitsev's wild deed to Pasha, he screams: "I'm sorry, Pasha! I understood everything! I will give up drinking! I will give up everything! I'm sorry, Pasha! I will not do it again! All! I gave up! I gave it up!"

Rublev's enlightenment is changed by the next video (the film "Prison teacher"). A teacher who has already aroused trust by his behavior and actions of the student who has been opposed to him for a long time convinces him to change his views on life and manner of behavior.

Teacher: - Do you want one-on-one

Student: -What do you want?

Teacher: - I do not want you to give up. You are too special to ruin your life like this.

Student continued to resist outwardly by inertia, but internally he began to see clearly: - It seems that you are looking for salvation yourself.

Teacher: -Gabriel, I know what it means when people give up. I know what it means to give up yourself. I just want to know that you are with me.

After some reflection, the student come closer to the teacher and stretches out his hand, making it clear that he has internally accepted his words and he is ready to draw conclusions.

In the last video (the film "Football team") the coach turns to the sportsmen, encouraging them to fight with themselves for self-improvement. There are noble, serious faces of young guys on the screen, in the eyes of which is the internal acceptance of the words of the coach and readiness for active action. The words of the coach logically complete the content of the previous video fragments:

And we should not be afraid of defeat. There is no place for fear in this struggle. If we go out on the field, be careful - we will doubt during our lives. But if we go out on the field and give to it absolutely everything - it will be heroism. Let's be the heroes! Let's be! Let's go, boys! Let's go!

Host: I wish our conversation continued in the infinite fragments of your own lives. Be wise! Listen to your inner voice and remember that you can be late forever!

Conclusions. The educational process provides an aftereffect when its core component is evaluated not only "by the eyes of the curriculum", but also by the "students' eyes", their interests, concerns, needs, value orientations. With this approach, it ceases to be purely cognitive process, becoming personally meaningful.

However, the successful aftereffect must be preceded by the clearly goal - the focus of the content and actions of the teacher need to affect not only the instrumental sphere of the individual, but also necessarily the motivational-value sphere. This goal becomes the compass which directs its actions on the result (those positive changes in the structure of the individual, which represent a productive aftereffect).

We will finish with the words of the third year student of the Institute of Foreign Languages - a reaction-response to the educational conversation "The Roads We Choose".

I smoked from the ninth grade. I did not consider my habit as harmful, although I heard, read, knew about the negative effects of smoking. When there was a conversation about it on the educational events, I thought: "Again about this... I will not hear anything new...". However, its content strongly influenced me, I was especially impressed with the fragment where the student of the 
Institute of Physical Education and Sports talked about the effects of smoking for future mothers, for young children. The facts were terrifying and caused serious reflections on what I was doing... The bell rang... Break ... When I left the university campus I took a cigarette... Before my eyes I saw a fragment of the film, the color of the skin of a small child, horror... I do not want to smoke! I will not smoke! I can't! I am grateful to the fate that I heard and understood such information on time.

Our further research will be carried out in the direction of analysis of the ways of influencing the motivational-value sphere of the individual in the process of studying pedagogical disciplines.

\section{Literature:}

1. Ushinskyi K. D. Collected works. - M .: Publishing house APN RSFSR, 1950 - Vol.9. - 628p.

2. Sukhomlinskyi V.O. How to raise a real person // Selected works in 5 volumes. - Vol.2. - K .: Rad. School, 1976. -

pp. 149-409.

3. Sukhomlinskyi V.O. One hundred tips for the teacher // Selected works in five volumes. - Vol.2. - K .: Rad. School, 1976. - pp. 419-657.

4. $\quad$ Galuziak V.M, Smetanskyi M.I., Shakhov V.I. Pedagogy: educational book. - Vinnitsa, 2003. - 415 p.

5. Maksymchuk, B. A., Ivanov, O. N., \& Lysiuk, S. P. (2010). Problems in developing students' readiness for independent physical education and sport activities. Physical Education, Sport and Health of the Nation, 10, 29-34.

6. Maksymchuk, B. A. (2010). Patterns and dynamics of the the future teacher's process of formation of the system of valeological qualities. Scientific Journal of M.P. Drahomanov National Pedagogical University, 15. Scientific-pedagogical problems of physical culture (physical culture and sport). 7, 163-167.

7. Maksymchuk, B. A. (2010). Forming the System of Ideological Formation of Future Teacher towards a Healthy Lifestyle. Modern Information Technologies and Innovative Methodologies of Learning in Training of Specialists: Methodology, Theory, Experience, Problems, 26, 385-388.

8. Maksymchuk, B. A. (2009). Features of planning mass participation sports events by future primary school teachers. Pedagogy, Psychology and Medical and Biological Problems of Physical Education and Sport, Kharkiv, 6, 99-102.

9. Maksymchuk, B. A., Ivanov, O. N., \& Lysiuk, S. P. (2009). Organizing mass participation sports events as a sociopedagogical problem. Relevant Problems of Physical Education and Methods of Sport Training, 145-155.

10. Maksymchuk, B. A. (2009). Bodybuilding lessons: methodical recommendations to the course on physical education. Vinnytsia: VDPU, 24.

11. Maksymchuk, B. A. (2009). A historical aspect of pedagogical support of a healthy lifestyle. Young Sports Science of Ukraine: a Collection of Scientific Works on Physical Education, Sport and Human Health, 13 (4), 115-119.

12. Maksymchuk, B. A. (2009). Formation of the future teacher's personality with the basics of a valeological worldview. Modern information technologies and innovative methods of studying in the training of specialists: methodology, theory, experience, problems. Kiev. Vinnytsia, 22, 379-383.

13. Maksymchuk, B. A. (2009). Valeological support for the humanitarization and humanization of the education system. Modern information technologies and innovative methods of studying in the training of specialists: methodology, theory, experience, problems. Kiev. Vinnytsia, 21, 171-176.

14. Maksymchuk, B. A. (2009). Physical culture with teaching methods: curriculum for students of Institute of Pedagogy and Psychology (by the requirements of the credit-modular system). Vinnitsa: VSPU, 20.

15. Maksymchuk, B. A. (2009). Philosophical aspects of the formation of valeological worldview. Physical culture, sports and health of the nation. Vinnytsia. V. 1. 8, 56-62.

16. Maksymchuk, B. A. (2008). Modernizing the national system of physical education by means of theoretical and methodological training of future primary school teachers. Scientific Notes of Vinnytsia State Pedagogical University. Series: Pedagogy and Psychology, 23, 228-232.

17. Maksymchuk, B. A. (2008). Physical culture (specialization judo): methodical recommendations to the course on physical education for non-specialists (specialization judo) according to the requirements of the credit and module framework. Vinnytsia. VSPU, 34.

18. Maksymchuk, B. A. (2016). The relevance of forming the future teachers' valeological competency. Kiev. Vinnytsia, 20, 390-394.

19. Maksymchuk, B. A. (2008). Forming health-improving knowledge in the history of teacher education. Scientific Notes of Mykhailo Kotsiubynskyi Vinnytsia State Pedagogical University. Series: Pedagogy and Psychology, 28, 232-237.

20. Maksymchuk, B. A. (2008). Athletic gymnastics: methodological recommendations to the course "Physical education". Vinnitsa, VSPU, 18.

21. Maksymchuk, B. A. (2008). The experience of organizing physical education for primary school pupils in Ukraine and countries of near and far. Young Sports Science of Ukraine: a Collection of Scientific Works on Physical Education, Sport and Human Health, 12 (2), 131-136.

22. Maksymchuk, B. A. (2007). Developing readiness in future primary school teachers to organize mass participation sports events in school. Modern Information Technologies and Innovative Methods of Specialist Training: Methodology, Theory, Experience, Problems, 15, 332-337.

23. Maksymchuk, B. A. (2007). Modelling readiness of future teachers to organize mass participation sports events: methodological recommendations. Vinnytsia. VSPU, 30.

24. Maksymchuk, B. A. (2010). Pedagogical problems of valeological education. Pedagogy and psychology. Vinnytsia, 32. 371-375.

25. Maksymchuk, B. A. (2009). Trends and prospects of future teacher training from the position of valeological approach. Topical problems of physical education and sports training methods. Vinnitsia, 65-69. 
26. Maksymchuk, B. A. (2009). Theoretical and methodological foundations for the formation of valeological worldview of a future teacher in the system of higher pedagogical education. Profesional Development of Personality: Problens and Perspectives. Khmelnytskyi, 282-286.

27. Maksymchuk, B. A. (2008). The problem of the formation of valeological competence at students of pedagogical universities. Pedagogy and psychology. Vinnytsia, 25. 211-214.

28. Maksymchuk, B. A. (2008). The process of forming the valeological worldview of the future teacher. Information telecommunications technologies in modern education: experience, problems, prospects. Lviv. Part. 2, 235-238.

29. Maksymchuk, B. A. (2008). Problems of modernization of the infrastructure of mass physical education of younger pupils. Modern information technologies and innovative methods of studying in the training of specialists: methodology, theory, experience, problems. Kiev-Vinnytsia. 17, 129-132.

30. Maksymchuk, B. A. (2008). Self-exercise activities. Topical problems of physical education and sports training methods. Vinnitsia, 51-58.

31. Maksymchuk, B. A. (2007). Preparation of future primary teachers for the organization of sports and mass work. PhD thesis. Vinnytsia, 225.

32. Maksymchuk, B. A. (2007). Training future primary school teachers from general education institutions to organize mass participation sports events for primary school pupils. Scientific Notes of Ternopil National Pedagogical University. Series: Pedagogy, 3, 30-35.

33. Maksymchuk, B. A. (2007). The process of training future primary school teachers to organize mass participation sports events as a pedagogical problem. Pedagogy, Psychology and Medical and Biological Problems of Physical Education and Sport, 6, 95-98.

34. Maksymchuk, B. A. (2007). The characteristics of future primary school teachers' methodical training to organize mass participation sports events. Relevant Problems of Physical Education and Methods of Sport Training, 50-53.

35. Maksymchuk, B. A. (2006). Features of planning mass participation sports events by future primary school teachers. Physical Education, Sport and Health of the Nation, 7, 345-349.

36. Maksymchuk, B. A. (2006). The structure of primary school teachers' pedagogical activity in physical education. Journal of Berdiansk State Pedagogical University (Pedagogical Sciences), 1, 129-134.

37. Maksymchuk, B. A. (2006). The essence of future primary school teachers' readiness for professional activity in physical education. New Learning Technologies, 45, 52-59.

38. Maksymchuk, B. A., \& Chernysh, M. S. (2006). Methodical characteristics of training future primary school teachers to organize mass participation sports events in the process of physical education. Relevant Problems of Physical Education and Methods of Sport Training, 56-59.

39. Maksymchuk, B. A. (2006). The use of innovative physical education technologies by future primary school teachers. Pedagogy and Psychology of Professional Education, 5, 70-77.

40. Maksymchuk, B. A. (2006). A definition-based analysis of key concepts of mass participation sports events. Problems of Education, 3, 129-132.

41. Maksymchuk, B. A. (2006). A didactic model of training future primary school teachers to organize mass participation sports events. Modern Information Technologies and Innovative Methods of Specialist Training: Methodology, Theory, Experience, Problems, 10, 383-387.

42. Maksymchuk, B. A. (2006). The efficiency of a didactic model of training future primary school teachers to organize sports events. Scientific Notes of Vinnytsia State Pedagogical University. Series: Pedagogy and Psychology, 18, 56-59.

43. Maksymchuk, B. A. (2005). The basic knowledge and skills of primary school teachers to organize mass participation sports events. Psychological and Pedagogical Problems of Rural School: the Collection of Scientific Works of Pavlo Tychyna Uman State Pedagogical University, 11, 42-46.

44. Maksymchuk, B. A. (2005). Professionally important personality traits of the organizer of mass participation sports events in primary school. Scientific Journal of Chernivtsi National University. Pedagogy and Psychology, 268, 110-115.

45. Maksymchuk, B. A. (2005). Professional and pedagogical activity of primary school teachers on physical education. Relevant Problems of Physical Education and Methods of Sport Training, 15-17.

46. Maksymchuk, B. A. (2005). Sports specialization as a method of training future primary school teachers to organize mass participation sports events. Scientific Notes of Vinnytsia State Pedagogical University. Series: Pedagogy and Psychology, 13, 41-43.

47. Maksymchuk, B. A. (2005). The characteristics of organization and problems of mass participation sports events in primary school. Modern Information Technologies and Innovative Methods of Specialist Training: Methodology, Theory, Experience, Problems, 7, 98-102.

48. Maksymchuk, B. A. (2004). Features of the manifestation of negative mental states at students. Physical culture, sports and health of the nation. Vinnytsia, 5, 435-439.

49. Makarenko A.S.About the explosion //Elected works in three volumes. - Vol.3. - K .: Rad. School, 1984. - P. 326-

\section{Література}

1. У Уинский К.Д. Собрание сочинений. - М.: Изд. АПН РСФСР, 1950. - Т.9. - 628с.

2. Сухомлинський В.О. Як виховати справжню людину // Вибрані твори в 5 томах. - Т.2. - К.: Рад. школа, 1976. - C. $149-409$.

3. Сухомлинський В.О. Сто порад учителеві // Вибрані твори в п'яти томах. - Т.2. - К.: Рад. школа, 1976. - С. 419-657. 
4. Галузяк В.М., Сметанський М.І., Шахов В.І. Педагогіка: навчальний посібник. - Вінниця, 2003. - 415с.

5. Максимчук Б. А. Іванов О.Н Лисюк С.П. Проблеми формування готовності студентів до самостійної фізкультурно-спортивної діяльності // Фізична культура, спорт та здоров'я нації /збірник наукових праць. - Випуск 10. Вінниця, 2010. - С. 29-34. Фахове видання

6.Максимчук Б. А. Закономірності й рушійні сили процесу формування в майбутнього вчителя системи валеологічних якостей / Б. А. Максимчук // Наук. часоп. Нац. пед. ун-ту ім. М. П. Драгоманова. Серія 15, Науково-педагогічні проблеми фізичної культури (фрізична культура і спорт) : зб. наук. пр. - Київ, 2010. - Вип. 7. - С. 163-167.

7.Максимчук Б. А. Формування системи світоглядного становлення майбутнього вчителя до здорового способу життя / Б.А. Максимчук // Сучасні інформаційні технології та інноваційні методики навчання в підготовці фрахівців: методологія, теорія, досвід, проблеми : зб. наук. пр. / Вінниц. держ. пед. ун-т ім. Михайла Коцюбинського, Ін-т магістратури, аспірантури, докторантури, Ін-т математики, фізики і технологій освіти ; Ін-т пед. освіти і освіти дорослих, Ін-т проф.-техн. освіти, Ін-т інформ. технологій і засобів навчання. - Київ ; Вінниця, 2010. - Вип. 26. - С. 385-388.

8. Максимчук Б. А. Особливості планування спортивно-масової роботи майбутніми вчителями початкової школи // Педагогіка, психологія та медико-біологічні проблеми фізичного виховання і спорту: Харків: ХДАДМ (ХХПІ), 2009. № 6. - с. 99-102. Фахове видання

9. Максимчук Б. А. Іванов О.Н., Лисюк С.П. Організація спортивно-масової роботи як соціально-педагогічна проблема // Актуальні проблеми фрізичного виховання та методики спортивного тренування. // Збірник наукових праць. Вінниця: ВДПУ, 2009. - С. 145-155.

10. Максимчук Б. А. Заняття з боді-білдінгу : метод. рек. до курсу «Фізичне виховання» / Б. А. Максимчук. Вінниця : ВДПУ, 2009. - 24 с.

11. Максимчук Б. А. Історичний аспект педагогічного забезпечення здорового способу житя / Б. А. Максимчук // Молода спортивна наука України : зб. наук. пр. з галузі фіз. виховання, спорту і здоров'я людини / Львів. держ. ін-т фріз. культури ім. Івана Боберського, Олімп. акад. України. - Львів, 2009. - Вип. 13, т. 4. - С. 115-119. Фахове видання

12. Максимчук Б. А. Формування особистості майбутнього вчителя з основами валеологічного світогляду / Б. А. Максимчук // Сучасні інформаційні технології та інноваційні методики навчання в підготовці фахівців: методологія, теорія, досвід, проблеми : зб. наук. пр. / Вінниц. держ. пед. ун-т ім. Михайла Коцюбинського, Ін-т магістратури, аспірантури, докторантури, Ін-т математики, фізики і технологій освіти ; Ін-т пед. освіти і освіти дорослих, Ін-т проф.-техн. освіти, Ін-т інформ. технологій і засобів навчання. - Київ ; Вінниця, 2009. - Вип. 22. - С. 379-383. Фахове видання

13. Максимчук Б. А. Валеологічний супровід гуманітаризації і гуманізації системи освіти / Б. А. Максимчук // Сучасні інформаційні технології та інноваційні методики навчання в підготовці фахівців: методологія, теорія, досвід, проблеми : зб. наук. пр. / Вінниц. держ. пед. ун-т ім. Михайла Коцюбинського, Ін-т магістратури, аспірантури, докторантури, Ін-т математики, фізики і технологій освіти ; Ін-т пед. освіти і освіти дорослих, Ін-т проф.-техн. освіти, Ін-т інформ. технологій і засобів навчання. - Київ ; Вінниця, 2009. - Вип. 21. - С. 171-176. Фахове видання

14. Максимчук Б. А. Фізична культура з методикою викладання : навчальна програма для студентів інституту педагогіки і психології (за вимогами кредитно-модульної системи) / Б. А. Максимчук. - Вінниця : ВДПУ, $2009 .-20$ с.

15. Максимчук Б. А. Філософські аспекти формування валеологічного світогляду / Б. А. Максимчук // Фізична культура, спорт та здоров'я нації : зб. наук. пр. / Вінниц. держ. пед. ун-т ім. Михайла Коцюбинського. - Вінниця, 2009. - Вип. 8, т. 1. - С. 56-62. Фахове видання

16. Максимчук Б. А. Модернізація національної системи фрізичного виховання шляхом теоретико-методичної підготовки майбутніх учителів початкових класів // Наукові записки Вінницького державного педагогічного університету. Серія: Педагогіка і психологія. - № 23. - Вінниця: ВДПУ, 2008. - С. 228-232. Фахове видання

17. Максимчук Б. А. Фізична культура (спеціалізація дзюдо) : метод. рек. до курсу «Фізичне виховання» для студентів неспеціал. ф-тів (спеціалізація дзюдо) за вимогами кредитно-модульної системи / Б. А. Максимчук. - Вінниця : ВДПУ, 2008. - 34 с.

18. Максимчук Б. А. Актуальність формування валеологічної компетентності майбутніх педагогів / Б. А. Максимчук // Сучасні інформаційні технології та інноваційні методики навчання в підготовці фахівців: методологія, теорія, досвід, проблеми : зб. наук. пр. / Вінниц. держ. пед. ун-т ім. Михайла Коцюбинського, Ін-т магістратури, аспірантури, докторантури, Ін-т математики, фізики і технологій освіти ; Ін-т пед. освіти і освіти дорослих, Ін-т проф.-техн. освіти, Ін-т інформ. технологій і засобів навчання. - Київ ; Вінниця, 2008. - Вип. 20. - С. 390-394. Фахове видання

19. Максимчук Б. А. Формування оздоровчих знань в історії педагогічної освіти / Б. А. Максимчук // Наук. зап. Вінниц. держ. пед. ун-ту ім.. Михайла Коцюбинського. Серія: Педагогіка і психологія. - Вінниця, 2008. - № 28. - С. $232-237$. Фахове видання

20. Максимчук Б. А. Атлетична гімнастика : метод. рек. до курсу «Фізичне виховання» для ін-тів і фр-тів / Б. А. Максимчук. - Вінниця : ВДПУ, 2008. - 18 с.

21. Максимчук Б. А. Досвід організації фрізичного виховання молодших школярів в Україні та країнах близького і далекого зарубіжжя / Б. А. Максимчук // Молода спортивна наука України : зб. наук. пр. з галузі фіз. виховання, спорту і здоров'я людини / Львів. держ. ін-т фіз. культури ім. Івана Боберського, Олімп. акад. України. - Львів, 2008. - Вип. 12, т. 2. С. 131-136. Фахове видання

22. Максимчук Б. А. Формування готовності майбутніх учителів початкових класів до організації спортивномасової роботи в школі // Сучасні інформаційні технології та інноваційні методики навчання у підготовці фрахівців: методологія, теорія, досвід, проблеми // Зб. наук. пр. - Вип. 15 / Редкол.: І.А. Зязюн (голова) та ін. - Київ-Вінниця: ДОВ "Вінниця", 2007. - С. 332-337. Фахове видання

23. Максимчук Б. А. Моделювання готовності майбутнього вчителя до проведення спортивно-масової роботи // 
Методичні рекомендації. - Вінниця: ВДПУ, 2007. - 30 с.

24. Максимчук Б. А. Педагогічні проблеми валеологічної освіти / Б. А. Максимчук // Наук. зап. Вінниц. держ. пед. ун-ту ім.. Михайла Коцюбинського. Серія : Педагогіка і психологія. - Вінниця, 2010. - № 32. - С. 371-375.

25. Максимчук Б. А. Тенденції та перспективи професійної підготовки майбутнього вчителя 3 позиції валеологічного підходу / Б. А. Максимчук // Актуальні проблеми фізичного виховання та методики спортивного тренування : зб. наук. пр. / Каф. теорії і методики спорту Вінниц. держ. пед. ун-ту ім. Михайла Коцюбинського. - Вінниця, 2009. - С. 65-69.

26. Максимчук Б. А. Теоретико-методологічні основи фрормування валеологічного світогляду майбутнього вчителя в системі вищої педагогічної освіти / Б. А. Максимчук // Професійне становлення особистості: проблеми і перспективи = Profesional Development of Personality: Problens and Perspectives : матеріали V міжнар. наук. -практ. конф., 22-24 жовт. 2009 р. / АПН України, Хмельниц. нац. ун-т, Ін-т педагогіки і психології проф. освіти, Ін-т проф.-техн. освіти ; [ред. кол.: Ничкало Н. Г. (наук. ред.) та ін.]. - Хмельницький, 2009. - С. 282-286.

27. Максимчук Б. А. Проблема формування валеологічної компетентності студентів педагогічних університетів / Б. А. Максимчук // Наук. зап. Вінниц. держ. пед. ун-ту ім. Михайла Коцюбинського. Серія : Педагогіка і психологія. - Вінниця, 2008. - № 25. - С. 211-214. Фахове видання

28. Максимчук Б. А. Процес формування валеологічного світогляду майбутнього педагога / Б. А. Максимчук // Інформаційно-телекомунікаційні технології в сучасній освіті: досвід, проблеми, перспективи : зб. наук. пр. / АПН України, Ін-т педагогіки і психології проф. освіти, Львів. держ. ун-т безпеки життєдіяльності ; редкол. М. М. Козяр (голов. ред.) та ін.]. Львів, 2008. - Ч. 2. - С. 235-238.

29. Максимчук Б. А. Проблеми модернізації інфраструктури масового фізичного виховання молодших школярів // Сучасні інформаційні технології та інноваційні методики навчання у підготовці фахівців: методологія, теорія, досвід, проблеми // Зб. наук. пр. - Вип. 17 / Редкол.: І.А. Зязюн (голова) та ін. - Київ-Вінниця: ДОВ "Вінниця", 2008. - С. $129-132$. Фахове видання

30. Максимчук Б. А. Самостійні заняття фрізичними вправами / Б. А. Максимчук // Актуальні проблеми фрізичного виховання та методики спортивного тренування : зб. наук. пр. / Каф. теорії і методики спорту Вінниц. держ. пед. ун-ту ім. Михайла Коцюбинського. - Вінниця, 2008. - С. 51-58.

31. Максимчук Б. А. Підготовка майбутніх учителів початкових класів до організації спортивно-масової роботи : дис. ... канд. пед. наук : 13.00.04 / Борис Анатолійович Максимчук ; Вінниц. держ. пед. ун-т ім. Михайла Коцюбинського. Вінниця, 2007. - 225 с.

32. Максимчук Б. А. Підготовка майбутніх учителів початкових класів загальноосвітньої школи до організації спортивно-масової роботи з молодшими школярами // Наукові записки Тернопільського національного педагогічного університету. Серія: Педагогіка. - 2007. - № 3. - С. 30-35. Фахове видання

33. Максимчук Б. А. Підготовка до організації спортивно-масової роботи майбутніх учителів початкових класів як педагогічна проблема // Педагогіка, психологія та медико-біологічні проблеми фізичного виховання і спорту: наукова монографія за редакцією проф. Єрмакова С.С. - Харків: ХДАДМ (ХХПІ), 2007. - С. 95-98. Фахове видання

34. Максимчук Б. А. Особливості методичної підготовки майбутніх учителів початкових класів до організації спортивно-масової роботи // Актуальні проблеми фізичного виховання та методики спортивного тренування // Зб. наук. пр. Вінниця: ВДПУ, 2007. - С 50-53.

35. Максимчук Б. А. Особливості планування спортивно-масової роботи майбутніми вчителями початкової школи // Фізична культура, спорт та здоров'я нації // Зб. Наук. пр. - Випуск 7 / Редкол.: К.П. Козлова (голова) та ін. - Вінниця: ДОВ "Вінниця", 2006. - С. 345-349. Фахове видання

36. Максимчук Б. А. Структура педагогічної діяльності вчителів початкової школи з фізичного виховання // Збірник наукових праць Бердянського державного педагогічного університету (Педагогічні науки). - №1. - Бердянськ: БДПУ, 2006. - С. 129-134. Фахове видання

37. Максимчук Б. А. Сутність готовності майбутнього вчителя початкової школи до професійної діяльності 3 фрізичної культури // Нові технології навчання: Науково-методичний збірник. - Випуск 45.-Київ. - 2006. - С. 52-59.

38. Максимчук Б. А. Черниш М. С. Методичні особливості підготовки майбутніх учителів початкових класів до організації спортивно-масової роботи у процесі фізичного виховання // Актуальні проблеми фрізичного виховання та методики спортивного тренування. // Збірник наукових праць. - Вінниця: ВДПУ, 2006. - С. 56-59.

39. Максимчук Б. А. Використання майбутніми вчителями початкової школи інноваційних технологій фрізичного виховання //Педагогіка і психологія професійної освіти. № 5. - Львів. - 2006. - С.70-77. Фахове видання

40. Максимчук Б. А. Дефрінітивний аналіз ключових понять спортивно-масової роботи // Проблеми освіти. Третій спец. випуск / Кол. авт. - К.: Інститут інноваційних технологій і змісту освіти Міністерства освіти і науки України, Вінницький соціально-економічний інститут Університету «Україна», 2006. - С. 129-132. Фахове видання

41. Максимчук Б. А. Дидактична модель підготовки майбутніх учителів початкової школи до організації спортивно-масової роботи // Сучасні інформаційні технології та інноваційні методики навчання у підготовці фрахівців: методологія, теорія, досвід, проблеми // Зб. наук. пр. - Вип. 10. / Редкол.: І.А. Зязюн (голова) та ін. - Київ-Вінниця: ДОВ "Вінниця", 2006. - С. 383-387. Фахове видання

42. Максимчук Б. А. Ефективність дидактичної моделі підготовки майбутніх учителів початкової школи до організації спортивно-масових заходів // Наукові записки Вінницького державного педагогічного університету. Серія: Педагогіка і психологія. - № 18. - Вінниця. - 2006. - С.56-59. Фахове видання

43. Максимчук Б. А. Основні знання й уміння учителя початкової школи для організації спортивно-масової роботи // Психолого-педагогічні проблеми сільської школи: Збірник наукових праць Уманського державного педагогічного університету імені Павла Тичини / Ред. кол.: Побірченко Н.С. (гол. ред.) та інші. - К.: Міленіум, 2005. - Випуск 11. - С. $42-46$. 
Фахове видання.

44. Максимчук Б. А. Професійно важливі якості особистості організатора спортивно-масової роботи в початковій школі // Науковий вісник ЧНУ. Збірник наукових праць. - Вип. 268. Педагогіка та психологія. - Чернівці: Рута, 2005. - С.110115. Фахове видання

45. Максимчук Б. А. Професійно-педагогічна діяльність із фізичного виховання вчителя початкової школи // Актуальні проблеми фізичного виховання та методики спортивного тренування // Збірник наукових праць. - Вінниця: ВДПУ, 2005. - C. 15-17.

46. Максимчук Б. А. Спортивна спеціалізація, як метод підготовки майбутніх учителів початкових класів до організації спортивно-масової роботи // Наукові записки Вінницького державного педагогічного університету / Серія: Педагогіка і психологія. - № 13. - Вінниця. - 2005. - С. 41-43. Фахове видання

47. Максимчук Б. А. Особливості організації та проблеми спортивно-масової роботи в школі 1-го ступеня // Сучасні інформаційні технології та інноваційні методики навчання у підготовці фахівців: методологія, теорія, досвід, проблеми // Зб. наук. пр. - Вип. 7. / Редкол.: І.А. Зязюн (голова) та ін. - Київ-Вінниця: ТОВ фірма "Планер", 2005. - С. 98-102. Фахове видання

48. Максимчук Б. А. Особливості прояву негативних психічних станів у студентів // Фізична культура, спорт та здоров'я нації // 3б. наук. пр. - Випуск 5 / Редкол.: К.П. Козлова (голова) та ін. - Вінниця: ДОВ "Вінниця", 2004. С. 435-439. Фахове видання

49. Макаренко А.С. О взрыве // Избр. произведения в трёх томах. - Т.3. - К.: Рад. школа, 1984. - С. $326-329$

DOI 10.31392/NPU-nc.series 15.2020.5(125).02

УДК: 796.332.015.1406

Балан Б. А.

старший викладач кафедри футболу

Національний університет фізичного виховання і спорту України, м. Київ

\section{АНАЛІЗ ЗМАГАЛЬНОЇ ДІЯЛЬНОСТІ КВАЛІФІКОВАНИХ ФУТБОЛІСТІВ НА ЕТАПІ ПІДГОТОВКИ ДО ВИЩИХ ДОСЯГНЕНЬ}

Сучасні тендениії розвитку спорту зумовлюють багаторічний планомірний процес досягнення вищої майстерності, диктують необхідність вдосконалення системи управління підготовкою атлетів в період переходу в професійний спорт. В статті розглянуто структуру техніко-тактичних дій кваліфрікованих футболістів у змагальній діяльності на етапі підготовки до вищих досягнень. Дані дослідження одержані із застосуванням сучасних технологій. Спостереження здійснювались за допомогою комп'ютерного аналізу відеозаписів матчів чемпіонату України з футтболу. Оцінено кількісні і швидкісні показники та дана характеристика пересувань гравців 19-20 років у матчах. Проаналізовано техніко-тактичні дії футболістів у змагальній діяльності. Результати дослідження структури техніко-тактичних дій кваліфікованих ффутболістів на етапі підготовки до вищих досягнень в умовах змагальної діяльності дозволили встановити високий рівень виконання практично всіх технічних прийомів, що у великій мірі обумовлено функціями у команді. Визначено необхідність впровадження системи поступового переходу спортсменів з юнацького футболу у професійний.

Ключеві слова: футбол, гравці, 19-20 рік, тренування, команди, змагання.

Балан Б.А. Анализ соревновательной деятельности квалифицированных футболистов на этапе подготовки к высшим достижениям. Современные тенденции развития спорта обусловливают многолетний планомерный процесс достижения высшего мастерства, диктуют необходимость совершенствования системы управления подготовкой атлетов в период перехода в профессиональньй спорт. В статье рассмотрена структура технико-тактических действий квалифицированных футболистов в соревновательной деятельности на этапе подготовки к высшим достижениям. Данные исследования получены с применением современных технологий. Наблюдение осуществлялись с помощью компьютерного анализа видеозаписей матчей чемпионата Украины по футболу. Оценены количественные и скоростные показатели и дана характеристика передвижений игроков 19-20 лет в матчах. Проанализированы технико-тактические действия футболистов в соревновательной деятельности. Результаты исследования структуры технико-тактических действий квалифицированных футтболистов на этапе подготовки к высшим достижениям в условиях соревновательной деятельности позволили установить высокий уровень исполнения практически всех технических приемов, что в большой степени обусловлено фуннкиями в команде. Определена необходимость внедрения системы постепенного перехода спортсменов из юношеского футбола в профрессиональный.

Ключевые слова: футбол, игроки, 19-20 лет, тренировка, команды, соревнования.

Balan B. An analysis of the competitive activity of skilled football players in the preparation stage for higher achievements. The problem of analysis of contention activity of skilled footballers on the stage of preparation to the higher achievements has an important theoretical and methodical value for an estimation and ground of traditional approaches of construction of educational-training process and system of realization of competitions in football.

On this time the far of researches is executed from the study of motive activity of footballers in the conditions of competitions, as a result of that the got is given about character and volume of actions of players both with a ball, and without him. 